\title{
AKTIVITAS ANTIOKSIDAN, SIFAT FISIK DAN SENSORIS ES KRIM DENGAN PENAMBAHAN SARI APEL
}

\author{
Antioxidant Activity, Physical, and Sensory Characteristics of Ice Cream with \\ the Addition of Apple Cider
}

\author{
Anisa Khairina*, Bambang Dwiloka, Siti Susanti \\ Program Studi Teknologi Pangan - Fakultas Peternakan dan Pertanian - Universitas Diponegoro \\ Jalan Prof. Soedarto, SH Tembalang, Semarang 1269 \\ *Penulis Korespondensi: email: anisakhrna@gmail.com
}

\begin{abstract}
ABSTRAK
Penelitian ini bertujuan untuk mengetahui proses pembutan, formulasi, aktivitas antioksidan, sifak fisik, dan sensoris es krim dengan penambahan sari buah apel agar tercipta produk es krim yang baik dengan faktor penambahan sari apel sebesar $0 \% ; 25 \%$; $50 \%$; dan $75 \%$. Rancangan Acak Lengkap (RAL) dengan 5 kali pengulangan digunakan dalam penelitian ini. Data yang diperoleh dianalisis dengan cara menguji langsung sampel sebanyak 2 perlakuan dengan masing-masing perlakuan menggunakan 2 pengulangan untuk aktivitas antioksidan, ANOVA untuk sifat fisik, sedangkan uji Kruskal Wallis digunakan untuk data organoleptik. Hasil penelitian menunjukkan penambahan sari apel menmeningkatkan aktivitas antioksidan dan berpengaruh nyata $(\mathrm{p}<0.05)$ terhadap overrun, resistensi pelelehan, dan total solid. Penambahan sari apel berpengaruh nyata $(p<0.05)$ terhadap aroma, rasa, tekstur, dan warna, sedangkan pada pengamatan secara keseluruhan atau overall tidak ada perbedaan yang nyata. Semakin tinggi penambahan sari apel menghasilkan peningkatan pada aktivitas antioksidan dan overrun dengan nilai aktivitas antioksidan tertinggi sebesar $14.867 \%$ dan rerata overrun tertinggi sebesar $36.46 \%$, serta penurunan terhadap resistensi pelelehan menjadi 65 menit 20 detik per $100 \mathrm{~g}$ es krim dan penurunan total solid dari $34.94 \%$ menjadi $21.18 \%$. Semakin tingginya penambahan sari apel juga berpengaruh terhadap meningkatnya aroma apel dan warna es krim yang dari putih menjadi cream, serta menurunnya rasa manis, tekstur menjadi kasar.
\end{abstract}

Kata kunci : Apel, Antioksidan, Es Krim, Overrun, Resistensi Pelelehan, Total Solid

\begin{abstract}
This research aim is to understand ice cream making process, to discover the right formulation to produce good quality ice cream, to find out antioxidant activities, physical, and sensory characteristics of ice cream with the addition of apple cider with each percentage of $0 \%, 25 \%, 50 \%$, and $75 \%$. Completely Randomized Design (RAL) with 5 times repetition was used for this research. Data obtained from analysis using descriptive for antioxidant activities, ANOVA for physical characteristics, and organoleptic for Kruska Wallis test. Result of the research showed that the addition of apple cider increased the antioxidant activities and had a real impact $(p<0.05)$ towards overrun, melting resistance, and total solid. The addition of apple cider gave a significant impact $(p<0.05)$ for aroma, flavour, texture, and colour, but did not have any visible impact to overall. Higher addition of apple cider generated growth on antioxidant activities and to overrun, resulting the highest antioxidant activities of $14.867 \%$ and the average number of highest overrun is at $36.46 \%$, it also caused decreasing level of melting resistance to 65 minutes 20 seconds per $100 \mathrm{~g}$ ice cream and reduction of total solid from $34.94 \%$ to $21.18 \%$. The higher addition of apple cider enhanced the apple aroma and changed the ice cream's colour from white to cream. It also lowered the sweetness and turned the texture rough.
\end{abstract}

Keywords : Apple, Antioxidant, Ice Cream, Melting Resistance, Overrun, Total Solid 


\section{PENDAHULUAN}

Es krim merupakan hidangan beku yang terbuat dari produk sapi perah seperti krim dan sejenisnya yang memiliki kandungan gizi tinggi dan banyak digemari masyarakat (Corradini et al., 2014; Aboulfazli et al., 2016; Nadelman et al., 2017). Perkembangan industri es krim di Indonesia semakin meningkat, banyak produk baru es krim bemunculan. Tahun 2003-2007 tingkat pertumbuhan pasar es krim Indonesia meningkat 20\% setiap tahunnya (Mien et al., 2008; afj, 2017; Canadean, 2018). Rasa produk es krim yang ada di pasaran saat ini masih kurang bervariasi, yaitu coklat, vanilla, dan strawberry, sehingga diperlukan inovasi membuat produk es krim dengan rasa baru, salah satunya rasa apel. Apel merupakan buah yang disukai masyarakat karena rasanya yang manis dan daging buahnya padat dan renyah, tetapi pengolahannya yang masih tergolong sangat sedikit. Penambahan sari buah apel diharapkan dapat menambah nilai aktivitas antioksidan pada es krim.

Buah apel kandungan utamanya mengandung quercetin dalam jumlah tinggi. Pada $100 \mathrm{~g}$ buah apel terkandung sekitar $4.42 \mathrm{mg}$ aglikon quercetin dan 13.2 glikosida quercetin (Cempaka et al., 2014). Quercetin merupakan antioksidan kuat yang termasuk dalam kelompok pigmen tanaman yang bertanggung jawab atas warna pada buah-buahan. Selain bermanfaat sebagai antioksidan, apel juga memiliki manfaat lain sebagai antiinflamasi, antialergi, antitrombosis, dan aktifitas antimicrobial. Apel juga dapat bertindak sebagai antideposit trigliserida, antikolestrol, dan antiviral. Apel juga bermanfaat untuk menurunkan kadar kolesterol, mencegah kanker kesehatan, menyehatkan paru-paru, mencegah penyakit jantung dan stroke, menurunkan berat badan, menjaga kesehatan gigi (Alberto et al., 2006). Apel juga mengandung pektin yang berfungsi untuk memperbaiki otot pencernaan dan mendorong sisa makanan pada saluran pembuangan (Qiu et al., 2009; Hyson, 2011; Samout et al., 2016).

Berdasarkan hal tersebut maka telah diadakan penelitian tentang pembuatan es krim dengan penambahan sari apel dengan penambahan yang berbeda. Tujuan dari penelitian ini adalah untuk mengetahui aktivitas antioksidan, sifat fisik yang meliputi overrun, resistensi pelelehan, total solid, dan sensoris es krim yang meliputi aroma, rasa, tekstur, warna, dan overall pada es krim dengan penambahan sari apel yang berbeda.

Manfaat dari penelitian ini adalah sebagai bahan informasi dalam pembuatan es krim yang memliki nilai manfaat bagi kesehatan bagi tubuh serta untuk meningkatkan nilai ekonomi buah apel. Manfaat lainnya adalah sebagai diversifikasi pangan olahan untuk alternatif sumber antioksidan selain antioksidan yang berbahan dasar dari kurma dan berries yang memiliki harga jauh lebih mahal daripada apel.

\section{BAHAN DAN METODE}

\section{Bahan}

Bahan-bahan yang digunakan dalam pembuatan es krim sari apel adalah buah apel, susu UHT merk Ultra, whipped cream merk Anchor, gula pasir merk Gulaku, kuning telur, $\mathrm{CMC}$, dan akuades.

\begin{abstract}
Alat
Alat-alat yang digunakan dalam pembuatan es krim sari apel adalah ice cream maker (Krisbow KI-2882), blender, mixer, neraca analitik, kain saring, pisau, panci, kompor, wadah plastik, saringan plastik, cawan porselin, desikator, bekker glass, stopwatch, refrigerator, freezer, dan oven
\end{abstract}

\section{Metode \\ Pembuatan Sari Apel}

Buah apel segar dicuci hingga bersih kemudian dipotong menggunakan pisau menjadi beberapa bagian kecil, kemudian dihaluskan menggunakan blender dengan penambahan akuades yang memiliki perbandingan 2:1 atau $1000 \mathrm{~g}$ buah apel:500 ml aquades. Selanjutnya, hasil yang didapat disaring menggunakan kain saring yang sudah disterilisasi terlebih dahulu dengan air panas.

\section{Pembuatan Es Krim}

Metode pembuatan es krim mengikuti prosedur Chan (2008) yang telah dimodifikasi. Hal yang pertama dilakukan adalah sterilisasi alat dan bahan kemudian menimbang berat bahan dengan neraca analitik lalu pencampuran semua bahan dicampur dengan menggunakan mixer. Formulasi adonan es krim dapat dilihat pada Tabel 1. Pasteurisasi dilakukan pada suhu $75^{\circ} \mathrm{C}$ selama 10 menit, lalu adonan disaring menggunakan saringan 
supaya memperoleh adonan dengan tekstur yang lebih lembut daripada sebelumnya. Selanjutnya dilakukan penambahan sari buah apel sebanyak $25 \%, 50 \%$, dan $75 \%$ dari adonan es krim. Adonan lalu dimasukkan ke dalam lemari es untuk proses agitasi selama 4-24 jam. Setelah itu dilakukan pengocokan adonan dengan menggunakan ice cream maker selama 30 menit. Terakhir, es krim disimpan di dalam freezer untuk persiapan pengujian. Formulasi adonan es krim dapat dilihat pada Tabel 1.

\section{Analisis Data}

Es krim diuji aktivitas antioksidan, overrun, resistensi pelelehan, total solid, aroma, rasa, tekstur, warna, dan overall es krim sari buah apel. Metode pengujian yang dilakukan adalah:

Pengujian aktivitas antioksidan dilakukan dengan metode DPPH, sampel 0.2 g ditambahkan $10 \mathrm{ml}$ etanol 95\% lalu divortex. Larutan tersebut disentifuse dengan kecepatan 4000 rpm selama 10 menit untuk memisahkan ekstrak antioksidan dengan endapan. Sebanyak $0.2 \mathrm{~mm}$ larutan 1,1-diphenyl-2picrylhydrazil (DPPH) dalam etanol 95\% disiapkan, kemudian $1 \mathrm{ml}$ dari larutan ini ditambahkan dengan $4 \mathrm{ml}$ ekstrak antioksidan (tingkat berkurangnya warna dari larutan menunjukkan efisiensi penangkap radikal). Larutan didiamkan selama 10 menit kemudian diukur absorbansinya pada panjang gelombang $517 \mathrm{~nm}$ (Zahro dan Nisa, 2015).

Pengujian overrun dilakukan dengan cara menghitung volume adonan es krim sebanyak $100 \mathrm{ml}$, kemudian ditimbang beratnya. Overrun es krim diperoleh dengan mengetahui berat adonan es krim dan berat es krim. Hal ini dilakukan sebelum dan setelah es krim di kocok menggunakan ice cream maker. Nilai overrun dihitung dengan selisih volume es krim dengan volume adonan es krim dibagi volume adonan es krim dikali 100\% (Avarez, 2009).

Resistensi pelelehan dihitung dengan cara mengukur suhu dan kelembaban ruangan, kemudian es krim diambil dengan berat yang sama (misalnya $100 \mathrm{~g}$ ) dan ditempatkan pada beaker glass, lalu dibekukan dalam freezer selama 24 jam. Selanjutnya, sampel yang berasal dari freezer diambil dan diletakkan pada suhu kamar dan dibiarkan sampai benar-benar meleleh semuanya dan catat waktunya (Zahro dan Nisa, 2015).
Prosedur analisis total solid sama seperti analisis kadar air (pengeringan dalam oven bersuhu $105{ }^{\circ} \mathrm{C}$ hingga konstan), namun dibedakan oleh rumus perhitungan persentase total solid. Total solid ditentukan dengan cara mencari berat awal bahan dengan berat bahan setelah di oven (Dewi, 2008).

Uji sensoris dilakukan menggunakan uji Hedonik yang meliputi kesukaan terhadap aroma, rasa, tekstur, serta warna dengan menggunakan 25 orang panelis semi terlatih. Data hasil pengujian overrun, resistensi pelelehan, dan total solid di analisis dengan menggunakan Analysis of Variance (ANOVA) dan jika terdapat perbedaan nyata pada taraf signifikansi 5\%, maka dilanjutkan dengan Uji Wilayah Ganda Duncan untuk mengetahui perbedaan antar perlakuan (Suwanda, 2011). Data hasil pengujian sensori dianalisis dengan menggunakan uji Kruskal Wallis pada taraf 5\%, kemudian dilanjutkan dengan uji Mann-Whitney apabila terdapat perbedaan yang nyata (Yanti, 2010). Sementara itu, data hasil uji aktivitas antioksidan di analisis secara deskriptif. Semua data dihitung dengan bantuan program SPSS versi 20 untuk Windows 10 .

\section{HASIL DAN PEMBAHASAN}

\begin{abstract}
Aktivitas Antioksidan
Hasil pengujian aktivitas antioksidan es krim sari apel dengan perlakuan penambahan sari apel 25\%,50\%, dan 75\% disajikan pada Gambar 1. Hasil pengujian aktivitas antioksidan es krim dengan penambahan sari apel memberikan peningkatan pada aktivitas oksidan es krim. Adanya kenaikan aktivitas antioksidan seiring dengan bertambahnya penambahan sari apel yang juga membuktikan bahwa terdapat sumber antioksidan pada buah apel. Pada penelitian ini, pembuatan sari apel tidak hanya menggunakan daging buah apelnya saja, tetapi juga beserta kulitnya, karena kulit apel mengandung antioksidan yang lebih tinggi dibandingkan dengan dagingnya. Hal ini sesuai dengan pendapat He dan Liu (2008) yang menyatakan bahwa antioksidan kulit apel enam kali lebih tinggi dibandingkan dengan daging buahnya.

Antioksidan yang terkandung di dalam apel dibagi menjadi dua yaitu an-
\end{abstract}


tioksidan primer dan antioksidan sekunder. Antioksidan primer pada apel merupakan senyawa fenolik golongan flavonoid yang dapat menghambat metabolisme mikroba dan antioksidan sekunder pada apel terdiri dari vitamin A dan vitamin C. Hal ini sesuai dengan pendapat Alberto et al. (2006) yang menyatakan bahwa kandungan flavonoid pada apel dapat menangkal pertumbuhan mikroba. Hal ini didukung oleh pernyataan Susanto dan Setyohadi (2011) yang menyatakan bahwa vitamin C dan vitamin A dalam apel merupakan antioksidan sekunder.

\section{Sifat Fisik Es Krim Sari Apel}

Penambahan sari apel memberikan pengaruh yang nyata $(\mathrm{p}<0.05)$ terhadap overrun es krim sari apel. Penambahan sari apel secara nyata $(p<0.05)$ meningkatkan overrun es krim sari apel. Hal ini dapat dilihat pada Tabel 2. Banyak atau sedikitnya udara yang terperangkap di dalam es krim karena proses agitasi dinamakan overrun. Semakin banyak udara yang terperangkap, maka semakin besar volume produk tersebut. Tinggi rendahnya overrun dipengaruhi proses homogenisasi, dimana selain mempengaruhi penangkapan udara juga berfungsi untuk mengubah partikel udara besar dipecah sehingga menjadi gelembung kecil pada saat berputarnya baling-baling mixer (Clarke, 2004; Sofjan dan Hartel, 2004). Overrun mempengaruhi tekstur dan kepadatan yang sangat menentukan kualitas es krim. Peningkatan udara menyebabkan es krim mudah untuk dilelehkan. Adanya udara dalam es krim akan membentuk rongga-rongga udara yang akan segera terlepas bersamaan dengan melelehnya es krim. Hal ini sesuai dengan pendapat Flores dan Goff (1999) yang menyatakan semakin banyak rongga udara akan menyebabkan es krim cepat menyusut dan meleleh pada suhu ruang.

Faktor lain yang mempengaruhi jumlah udara yang terperangkap yaitu komposisi yang terdapat pada es krim sari apel menghasilkan overrun tinggi karena jumlah padatan yang terdapat pada adonan es krim lebih rendah. Penambahan cairan dalam jumlah besar maka akan menurunkan jumlah padatan adonan yang akan mengakibatkan nilai overrun meningkat (Farida, 2005; da silva et al., 2015; McGhee et al., 2015; Balthazar et al., 2017). Overrun es krim cenderung meningkat seiring dengan adanya penambahan sari apel. Hal ini didukung oleh penda- pat Suprayitno et al. (2001) yang menyatakan bahwa semakin menurunnya viskositas adonan, air bebas yang tidak terikat dalam adonan dapat menurunkan tegangan permukaan sehingga udara lebih mudah menembus permukaan adonan dan pengembangan es krim akan lebih tinggi. Es krim yang berkualitas memiliki overrun $70-80 \%$, sedangkan untuk industri rumah tangga $35-50 \%$. Hal ini menunjukkan bahwa es krim sari apel T2 (50\%) dan T3 (75\%) sudah termasuk dalam kategori es krim industri rumah tangga.

Berdasarkan hasil pengujian, terlihat bahwa penambahan sari apel memberikan pengaruh yang nyata $(\mathrm{p}<0.05)$ terhadap resistensi pelelehan es krim sari apel. Penambahan sari apel secara nyata $(p<0.05)$ menurunkan resistensi pelelehan es krim sari apel. Kecepatan leleh berkisar antara 6.4-10.6 menit/10 g. Hasil pengujian menunjukkan bahwa resistensi pelelehan es krim sari apel masih belum sesuai dengan SNI No. 01-37131995 yang didalamnya dinyatakan bahwa resistensi pelelehan es krim berkisar 15-25 menit. Jika dilihat dari hasil, dapat diketahui bahwa resistensi pelelehan es krim sari apel semakin menurun. Lama waktu leleh berhubungan juga dengan nilai overrun, semakin tinggi nilai overrun maka akan semakin cepat waktu lelehnya. Hal ini sesuai dengan pendapat Akesowan (2008) yang menyatakan bahwa es krim mudah meleleh karena adanya peningkatan udara pada es krim. Kecepatan leleh es krim cenderung menurun seiring dengan penambahan sari apel. Semakin banyak penambahan sari apel maka kecepatan leleh akan mengalami peningkatan (semakin cepat leleh). Penurunan waktu pelelehan disebabkan karena penurunan bahan padat es krim akibat pemecahan gula menjadi $\mathrm{CO}_{2}$. Hal ini sesuai dengan pendapat Zahro dan Nisa (2015) yang menyatakan bahwa semakin sedikitnya total padatan pada es krim yang berakibat menurukan kecepatan lelehnya.

Penurunan jumlah total padatan dapat meningkatkan titik beku adonan sehingga air yang terperangkap semakin sedikit dan meningkatkan mobilitas air bebas. CMC juga memiliki pengaruh terhadap waktu leleh es krim. Hal ini sesuai dengan pendapat Widiantoko dan Yunianta (2014) yang menyatakan bahwa apabila penstabil didispersikan pada fase cair, maka penstabil akan mengikat sejumlah besar air dan membentuk kerangka gel yang dapat mencegah molekul air berger- 
ak bebas dan membentuk selaput yang terbentuk akan melindungi komponen es krim dari pengaruh suhu luar dan membatasi mobilitas air pada emulsi sehingga menurunnya jumlah air bebas yang terperangkap. Hal ini didukung oleh pendapat Muse dan Hartel (2004) yang menyatakan bahwa penurunan jumlah air bebas yang terperangkap akan menghasilkan es krim yang cepat meleleh.

Berdasarkan hasil pengujian terlihat bahwa penambahan sari apel memberikan pengaruh yang nyata $(\mathrm{p}<0.05)$ terhadap total padatan es krim sari apel. Penambahan sari apel secara nyata $(\mathrm{p}<0.05)$ menurunkan total padatan es krim sari apel. Hasil pengujian dapat menunjukkan bahwa hanya total padatan es krim sari apel T0 yang sesuai dengan SNI No. 01-3713-1995 yang di dalamnya dinyatakan bahwa standar minimal total padatan es krim adalah 34\%. Jika dilihat dari hasil T0, T1, T2, dan T3 dapat diketahui bahwa total padatan es krim sari apel semakin menurun dikarenakan total padatan berbanding lurus dengan resistensi pelelehan, tetapi berbanding terbalik dengan overrun. Hal ini sesuai dengan pendapat Widiantoko dan Yunianta (2014) yang menyatakan bahwa semakin tinggi nilai overrun pada es krim, maka semakin rendah total padatannya dan semain cepat waktu yang dibutuhkan es krim untuk meleleh.

Total padatan es krim semakin rendah seiring dengan penambahan sari apel. Sari apel memiliki kandungan total padatan yang rendah sehingga semakin banyak sari apel yang ditambahkan ke dalam formulasi es krim, dengan formulasi bahan dasar yang sama, maka akan menyebabkan penurunan total padatan es krim. Hal ini sesuai dengan pendapat Purnamayati (2008) yang menyatakan bahwa penurunan total padatan seiring dengan penambahan sari apel diduga karena sari apel memiliki kandungan total padatan yang rendah, sedangkan total padatan adonan (susu, gula, dan whipped cream) memiliki total padatan yang tinggi sehingga semakin tinggi penambahan sari apel maka total padatan es krim akan semakin menurun. Hal ini didukung oleh pendapat El-Samahy et al. (2009) yang menyatakan bahwa komponen padatan dalam adonan akan mempengaruhi total padatan produk. Komponen-komponen yang terukur sebagai total padatan yaitu sukrosa, gula pereduksi, asam-asam organik, dan protein (Doan dan Livak, 1945; Muafi, 2004; Clarke, 2005).

\section{Sifat Sensoris Es Krim Sari Apel}

Pengujian sifat sensoris es krim sari apel meliputi aroma, rasa, tekstur, warna, dan overall. Hasil pengujian dari masingmasing parameter sensoris dapat dilihat pada Tabel 3.

Berdasarkan hasil uji organoleptik aroma es krim sari apel terlihat bahwa penambahan sari apel memberikan pengaruh yang nyata $(\mathrm{p}<0,05)$ terhadap aroma es krim sari apel. Aroma es krim sangat dipengaruhi oleh bahan-bahan yang digunakan dalam menyusun campuran es krim. Hal ini sesuai dengan pendapat Hartatie (2011) yang menyatakan bahwa bahan-bahan yang digunakan untuk penelitian ini sudah melalui proses pengujian kualitas sehingga merupakan bahan-bahan yang berkualitas baik sehingga tidak terdapat penyimpangan aroma dari bahan-bahan tersebut seperti aroma tengik, pahit, sangit (cooked flavor), metalik, dan sebagainya. Dengan demikian, tidak terjadi cacat aroma pada es krim. Aroma es krim lebih ditentukan oleh lemak susu dan skim yang ditambahkan. Hal ini sesuai dengan pendapat Hendriani (2005) yang menyatakan bahwa aroma es krim sebagian besar didominasi oleh aroma susu. Peningkatan rerata skor pada tiap perlakuan menunjukkan bahwa semakin banyak penambahan sari apel yang ditambahankan pada es krim maka membuat aroma susu pada es krim semakin menurun. Hal ini dikarenakan formulasi sari apel yang ditambahkan ke es krim pada tiap perlakuan.

Berdasarkan hasil uji organoleptik rasa es krim sari apel, terlihat bahwa penambahan sari apel memberikan pengaruh yang nyata $(p<0.05)$ terhadap rasa es krim sari apel. Rasa pada es krim merupakan kombinasi antara cita rasa dan bau. Mutu dan rasa enak dari es krim dipengaruhi oleh gula, stabilizer, dan bahan kering tanpa lemak. Hal ini sesuai dengan pendapat Hartatie (2011) yang menyatakan bahwa gula berfungsi memperbaiki tekstur, meningkatkan kekentalan, dan memberikan rasa manis. Penurunan rerata skor pada tiap perlakuan menunjukkan bahwa semakin banyak penambahan sari apel yang ditambahkan pada es krim maka membuat rasa manis pada es krim semakin menurun. Menurunnya rasa manis pada es krim tidak diakibatkan oleh kadar gula karena setiap perlakuan menggunakan formulasi kadar gula yang seragam. Hal ini dikarenakan bertambahnya formulasi sari apel pada tiap perlakuan. Apel memiliki rasa manis 
Tabel 1. Formulasi es krim sari apel

\begin{tabular}{|c|c|c|c|c|}
\hline \multirow{3}{*}{ Bahan (g) } & \multicolumn{4}{|c|}{ Berat Bahan } \\
\hline & $\mathrm{T}_{0}$ & $\mathrm{~T}_{1}$ & $\mathrm{~T}_{2}$ & $\mathrm{~T}_{3}$ \\
\hline & $0 \%$ & $25 \%$ & $50 \%$ & $75 \%$ \\
\hline Susu segar & 130 & 130 & 130 & 130 \\
\hline Krim susu & 22 & 22 & 22 & 22 \\
\hline Gula pasir & 27 & 27 & 27 & 27 \\
\hline Kuning telur & 20 & 20 & 20 & 20 \\
\hline $\mathrm{CMC}$ & 1 & 1 & 1 & 1 \\
\hline Sari Apel & 0 & 50 & 100 & 150 \\
\hline Total (g) & 200 & 250 & 300 & 350 \\
\hline
\end{tabular}

Tabel 2. Karakteristik fisik es krim sari apel

\begin{tabular}{|c|c|c|c|}
\hline Penambahan Sari Apel & \multicolumn{3}{|c|}{ Parameter Fisik } \\
\cline { 2 - 4 }$(\mathbf{0})$ & Overrun & Resistensi Pelelehan & Total Solid \\
\hline 0 & $31.64 \pm 0.235^{\mathrm{a}}$ & $106.20 \pm 3.701^{\mathrm{a}}$ & $34.94 \pm 0.131^{\mathrm{a}}$ \\
\hline 25 & $33.48 \pm 0.242^{\mathrm{b}}$ & $94.20 \pm 2.387^{\mathrm{b}}$ & $27.50 \pm 0.517^{\mathrm{b}}$ \\
\hline 50 & $35.60 \pm 0.124^{\mathrm{c}}$ & $85.20 \pm 2.588^{\mathrm{c}}$ & $24.30 \pm 0.750^{\mathrm{c}}$ \\
\hline 75 & $36.46 \pm 0.343^{\mathrm{d}}$ & $64.80 \pm 3.271^{\mathrm{d}}$ & $21.18 \pm 0.825^{\mathrm{d}}$ \\
\hline
\end{tabular}

Keterangan: Superskrip huruf yang berbeda pada kolom yang sama, menunjukkan terdapat perbedaan nyata $(\mathrm{p}<0.05)$

Tabel 3. Hasil uji sensoris es krim sari apel

\begin{tabular}{|c|c|c|c|c|c|}
\hline \multirow{2}{*}{$\begin{array}{c}\text { Penambahan } \\
\text { Sari Apel (\%) }\end{array}$} & Aroma & Rasa & Tekstur & Warna & Overall \\
\cline { 2 - 6 } & $1.00 \pm 0.000^{\mathrm{a}}$ & $3.60 \pm 0.707^{\mathrm{a}}$ & $3.12 \pm 0.971^{\mathrm{a}}$ & $2.04 \pm 0.978^{\mathrm{a}}$ & $3.04 \pm 0.888$ \\
\hline 0 & $1.84 \pm 0.850^{\mathrm{b}}$ & $3.04 \pm 0.850^{\mathrm{b}}$ & $2.84 \pm 1.027^{\mathrm{ab}}$ & $3.00 \pm 0.957^{\mathrm{b}}$ & $2.88 \pm 0.832$ \\
\hline 25 & $2.20 \pm 0.645^{\mathrm{b}}$ & $2.32 \pm 0.645^{\mathrm{c}}$ & $2.60 \pm 0.866^{\mathrm{bc}}$ & $3.32 \pm 0.690^{\mathrm{b}}$ & $2.48 \pm 0.918$ \\
\hline 50 & $2.16 \pm 0.687^{\mathrm{b}}$ & $2.28 \pm 0.687^{\mathrm{c}}$ & $2.20 \pm 0.912^{\mathrm{c}}$ & $3.44 \pm 0.711^{\mathrm{b}}$ & $2.44 \pm 0.768$ \\
\hline 75 & &
\end{tabular}

Keterangan: Superskrip huruf yang berbeda pada kolom yang sama, menunjukkan terdapat perbedaan nyata $(\mathrm{p}<0.05)$

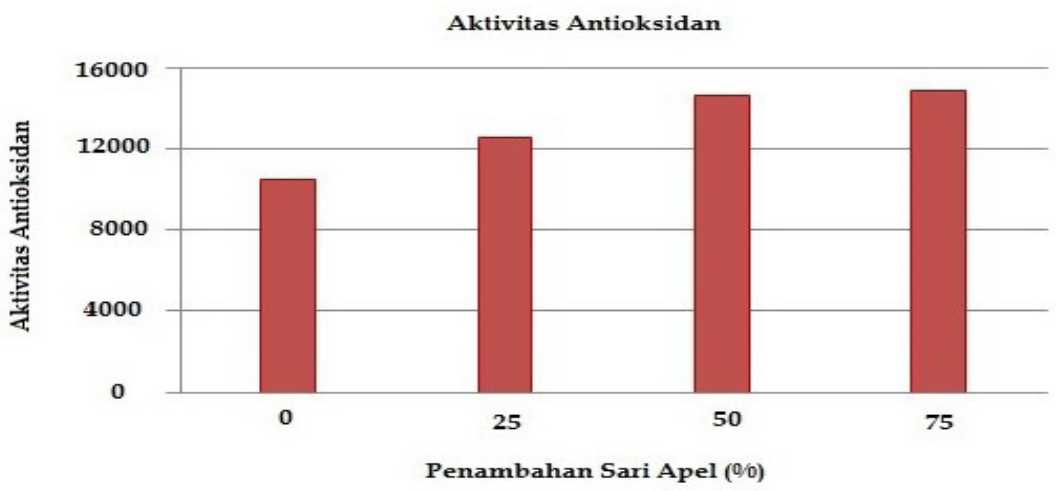

Gambar 1. Grafik rerata aktivitas antioksidan es krim sari apel 
yang disertai rasa asam. Hal ini sesuai dengan pendapat Sufrida (2007) yang menyatakan bahwa apel memiliki rasa yang segar dan sedikit asam, daging buah keras dengan warn putih serta bertekstur halus.

Berdasarkan hasil uji organoleptik tekstur es krim sari apel terlihat bahwa penambahan sari apel memberikan pengaruh yang nyata $(p<0.05)$ terhadap tekstur es krim sari apel. Tekstur adalah keadaan partikel-partikel yang menyusun keseluruhan es krim. Tekstur es krim sangat dipengaruhi oleh lemak sebagai bahan baku es krim. Lemak pada ice cream befungsi untuk memberi tekstur yang halus, berkontribusi dengan rasa serta memberi efek sinergis dengan flavor yang ditambahkan dan memperindah penampakan (Ismunandar, 2004; Ayed et al., 2017; Pintor-Jordines et al., 2018). Penurunan rerata skor pada tiap perlakuan menunjukkan bahwa semakin banyak penambahan sari apel yang ditambahkan pada es krim maka membuat tekstur pada es krim semakin kasar. Menurunnya tingkat kelembutan es krim disebabkan karena sari apel memiliki kandungan lemak yang sangat rendah sehingga tidak tejadi peningkatan kadar lemak yang terlalu tinggi pada es krim. Hal ini sesuai dengan pendapat Sutrisno dan Susanto (2014) yang menyatakan bahwa kandungan lemak susu terlalu rendah akan membuat kristal es besar dan tekstur lebih kasar serta terasa lebih dingin.

Berdasarkan hasil uji organoleptik warna es krim sari apel terlihat bahwa penambahan sari apel memberikan pengaruh yang nyata $(p<0.05)$ terhadap warna es krim sari apel. Peningkatan rerata skor pada tiap perlakuan menunjukkan bahwa semakin banyak penambahan sari apel yang ditambahkan pada es krim maka membuat warna pada es krim semakin cream atau cenderung lebih gelap daripada es krim kontrol. Meningkatnya warna es krim menjadi warna cream dipengaruhi oleh banyaknya formulasi sari apel yang ditambahkan ke es krim. Menggelapnya warna es krim sari apel dikarenakan apel sangat mudah mengalami perubahan warna menjadi coklat akibat oksidasi setelah mengalami proses pemotongan. Hal ini sesuai dengan pendapat Rojas-Grau et al. (2006) yang menyatakan bahwa pencoklatan enzimatik dipicu oleh reaksi oksidasi yang dikatalisis oleh enzim fenol oksidase. Perubahan warna es krim yang menjadi lebih gelap (cream) dapat membuat es krim terlihat lebih menarik karena warna es krim tidak hanya putih seperti es krim pada biasanya. Warna cream tidak mempengaruhi kualitas fisik es krim sari apel. Hal ini tidak sesuai dengan pendapat Supapvanich et al. (2011) yang menyatakan bahwa pencoklatan memiliki pengaruh yang besar terhadap nilai jual karena mempengaruhi penampilannya

Berdasarkan hasil uji organoleptik overall es krim sari apel terlihat bahwa penambahan sari apel tidak memberikan pengaruh yang nyata terhadap overall es krim sari apel. Penurunan rerata skor pada tiap perlakuan menunjukkan bahwa semakin banyak penambahan sari apel yang ditambahkan pada es krim maka membuat tingkat kesukaan pada es krim semakin menurun. Berkurangnya tingkat kesukaan pada es krim bisa disebabkan oleh sifat fisik es krim yang mempengaruhi tingkat kesukaan panelis. Tekstur es krim seiring dengan bertambahnya formulasi sari apel menjadi yang semakin kasar sehingga menimbulkan efek lebih dingin dan menjadi kurang disukai. Berkurangnya rasa manis pada setiap penambahan formulasi sari apel juga menjadi faktor menurunnya tingkat kesukaan panelis. Hal ini sesuai dengan pendapat Asriyadi (2011) yang menyatakan bahwa es krim adalah jenis frozen dessert yang sangat digemari oleh masyarakat karena rasanya yang manis dan teksturnya yang lembut. Pendapat lainnya juga menyatakan bahwa kesukaan konsumen pada produk es krim sangat dipengaruhi oleh rasa, bau, rangsangan mulut, dan teksturnya (Bower dan Baxter, 2000; da Silva et al., 2014).

\section{SIMPULAN}

Penambahan sari apel memberikan pengaruh terhadap antivitas antioksidan, sifak fisik dan sensoris es krim. Aktivitas antioksidan tertinggi sebesar $14.867 \%$, overrun meningkat, sedangkan resistensi pelelehan dan total solid mengalami penurunan. Pada organoleptik, uji aroma dan warna mengalami peningkatan, sedangkan rasa, tekstur, dan kesukaan mengalami penurunan. Es krim dengan penambahan $50 \%$ sari apel dinilai sebagai es krim dengan formulasi penambahan sari apel yang paling sesuai dibandingkan dengan yang lainnya. Secara keseluruhan kualitas es krim tetap dinilai baik dan layak. 
Jurnal Teknologi Pertanian Vol. 19 No. 1 [April 2018] 59-68

Aktivitas Antioksidan, Sifat Fisik dan Sensoris Es Krim [Khairina dkk]

\section{DAFTAR PUSTAKA}

Aboulfazli, F, Shori, A, B, Baba, A, S. 2016. Effects of the replacement of cow milk with vegetable milk on probiotics and nutritional profile of fermented ice cream. LWT-Food Science and Technology. 70:261-270

afj. 2017. Ice cream whips up global sales of 13 billion liters in 2016. Dilihat 20 September 2017. <https://www.asiafoodjournal.com/2017/07/ice-creamglobal-sales-13-billion/2/>

Akesowan, A. 2008. Effect of combined stabilizers containing konjac flour and carrageenan on ice cream. AU J. T. 12(2):81-85

Alberto, M, R, Canavosio, M, A, R, de Nadra, M, C, M. 2006. Antimicrobial effect of polyphenols from apple skins on human bacterial pathogens. Electronic Journal of Biotechnology. 9(3):205

Asriyadi, H. 2011. Pengaruh Substitusi Ubi Jalar (Ipomea batatas) dengan Susu Skim Terhadap Pembuatan Es Krim. Skripsi. Universitas Hasanuddin. Makasar

Avarez, AV. 2009. 'Ice Cream and Relaten Product'. Dalam S Clark, M Costello, M Drake, F Bodyfelt (eds.). The Sensory Evaluation of Dairy Product. Springer, New York

Ayed, C, Martins, S, I, F, S, Williamson, A, M, Guichard, E. 2017. Understanding fat, proteins and saliva impact on aroma release from flavoured ice creams. Food Chemistry.

Balthazar, C, F, Silva, H, L, A, Cavalcanti, R, N, Esmerino, E, A, Cappato, L, P, Abud, Y, K, D, Moraes, J, Andrade, M, M, Freitas, M, Q, Sant'Anna, C, Raices, R, S, L, Silva, M, C, Cruz, A, G. 2017. Prebiotics addition in sheep milk ice cream: a rheological, microstructural and sensory study. Journal of Functional Foods. 35:564-573

Bower, J, A, Baxter, I, A. 2000. Consumer perception of the nature and quality of homemade and commercial dairy ice cream. British Food Journal. 102(11):821837

Canadean. 2018. Consumer and market insights : ice cream market in indonesia. Dilihat 2 Januari 2018. <https://www. marketresearch.com/product/sam- ple-9053591.pdf>

Cempaka, A, R, Santoso, S, Tanuwijaya, L, K. 2014. Pengaruh metode pengolahan (juicing dan blending) terhadap kandungan quercetin berbagai varietas apel lokal dan impor. IJHN. 1(1):14-22

Chan, LA. 2008. Membuat Es Krim. Agromedia Pustaka, Jakarta

Clarke, C. 2004. The Science of Ice Cream. Cornwall, England

Clarke, C. 2005. The science of ice cream. Chemistry and Industry. 24(19):22-23

Corradini, S, A, S, Madrona, G, S, Visentainer, J, V, Bonafe, E, G, Carvalho, C, B, Roche, P, M, Prado, I, N. 2014. Sensorial and fatty acid profile of ice cream manufactured with milk of crossbred cows fed palm oil and coconut fat. Journal of Dairy Science. 97(11):67456753

da silva P, D, L, Bezerra, M, F, Santos, K, M, O, Correia, R, T, P. 2015. Potentially probiotic ice cream from goat's milk: Characterization and cell viability during processing, storage and simulated gastrointestinal conditions. LWT-Food Science and Technology. 62:452-457

da Silva, V, M, Minim, V, P, R, Ferreira, M, A, M, Souza, P, H, P, Moraes, L, E, S, Minim, L, A. 2014. Study of the perception of consumers in relation to different ice cream concepts. Food Quality and Preferences. 36:161-168

Dewi, P. 2008. Kajian Penggunaan Susu Kedelai Sebagai Substitusi Susu Sapi Terhadap Sifat Es Krim Ubi Jalar (Ipomoea batatas). Tesis. Universitas Sebelas Maret. Surakarta

Doan, F, J, Livak, C, W. 1945. The determination of total solids in liquid dairy products by drying with forced heated air results with ice-cream mix and sweetened-condensed milk. Journal of Dairy Science. 28(12):921-926

El-Samahy, S, K, Youssef, K, M, MoussaAyoub, T, E. 2009. Producing ice cream with concentrated cactus pear pulp: a preliminary study. Journal PACD. 11:112

Farida, Z. 2005. Kekerasan dan Overrun Es Krim yang dibuat Menggunakan Susu Sapi Maupun Susu Kambing dengan Persentase Gula yang Berbeda. Skripsi. Universitas Jenderal Soedirman. Purwokerto

Flores, A, A, Goff, H, D. 1999. Ice crystal size 
distributions in dynamically frozen model solutions and ice cream as affected by stabilizers. Journal Dairy Science. 82(7):1399-1407

Hartatie, E, S. 2011. Kajian formulasi (bahan baku, bahan pemantap) dan metode pembuatan terhadap kualitas es krim. Jurnal Gamma. 7(1):20-26

He, X, Liu, R, H. 2008. Phytochemicals of apple peels: isolation, structure elucidation, and their antiproliferative and antiocxidant activities. J. Agric. Food Cm. 56(21):9905-9910

Hendriani, Y. 2005. Stabilitas Es krim yang diberi Khitosan sebagai Bahan Penstabil pada Konsentrasi yang Berbeda. Skripsi. IPB. Bogor

Hyson, D, A. 2011. A comprehensive review of apples and apple components and their relationship to human health. Adv Nutr. 2(5):408-420

Ismunandar. 2004. Dibalik Lembutnya Es Krim. Kanisius, Yogyakarta

McGhee, C, E, Jones, J, O, Park, Y, W. 2015. Evaluation of textural and sensory characteristics of three types of low-fat goat milk ice cream. Small Ruminant Research. 123-293-300

Mien, K, Mahmud, Hermana, Zulfianto, NA, Rozana, R, Apriyantono. 2008. Tabel Komposisi Pangan Indonesia (TKPI). Elex Media Komputindo, Jakarta

Moriano, M, E, Alamprese, C. 2017. Organogels as novel ingredients for low saturated fat ice creams. LWT. 86:371-376

Muafi, K. 2004. Produksi Asam Asetat Kasar dari Jerami Nangka. Skripsi. Universitas Brawijaya. Malang

Muse, M, R, Hartel, R, W. 2004. Ice cream structural elements that affect melting rate and hardness. J. Dairy Sci. 87(1):110

Nadelman, P, Frazão, J, V, Viera, T, I, Balthazar, C, F, Andrade, M, M, Cruz, A, G, Fonseca-Gonçalvesa, A, Maia, C. 2017. The performance of probiotic fermented sheep milk and ice cream sheep milk in inhibiting enamel mineral loss. Food Research International. 97:184-190

Pintor-Jordines, A, .Arjona-Román, J, L, Totosaus-Sánchez, A, Severiano-Pérez, P, González-González, L, R, EscalonaBuendia, H, B. 2018. The influence of agave fructans on thermal properties of low-fat, and low-fat and sugar ice cream. LWT. 93:679-685

Purnamayati, L. 2008. Kajian Substitusi Krim Dengan Daging Buah Alpukat Terhadap Sifat Es Krim. Skripsi. Universitas Sebelas Maret. Surakarta

Qiu, N, X, Tian, Y, X, Qiao, S, T, Deng, H. 2009. Apple pectin behavior separated by ultrafiltration. Agricultural Sciences in China. 8(10):1193-1202

Rojas-Grau, M, A, Lopez, S, A, Tapia, Belloso, O, M. 2006. Browning inhibition in fresh-cut 'fuji' apple slices by natural antibrowning agents. Journal of Food Science. 71(1):59-65

Sofjan, R, Hartel, R, W. 2004. Effects of overrun on structural and physical characteristics of ice cream. International Dairy Journal. 114(3):255-262

Samout, N, Bouzenna, H, Dhibi, S, Ncib, S, ElFeki, A, Hfaiedh, N. 2016. Therapeutic effect of apple pectin in obese rats. Biomedicine $\mathcal{E}$ Pharmacotherapy. 83:1233-1238

Sufrida, Y. 2007. Khasiat dan Manfaat Apel. Agromedia Pustaka, Jakarta

Supapvanich, S, Pimsaga, J, Srisujan, P. 2011. Physicochemical changes in fresh-cut wax apple (Syzygium samarangenese [Blume] Merrill \& L.M. Perry) during storage. Food Chemistry. 127(3):912-917

Suprayitno, E, H, Kartikaningsih, Rahayu, S. 2001. Pembuatan es krim dengan menggunakan stabilisator natrium alginat dari Sargassum sp. Jurnal Makanan Tradisional Indonesia. 1(3):23-27

Susanto, W, H, Setyohadi, B, R. 2011. Pengaruh varietas apel (Mallus sylvestris Mill.) dan lama fermentasi khamir Saccharomices cerevisiae sebagai perlakuan pra-pengolahan terhadap karakteristik sirup. Jurnal Pangan dan Agroindustri. 1(3):135-142

Sutrisno, C, D, N, S, Susanto, W, H. 2014. Pengaruh penambahan jenis dan konsentrasi pasta (santan dan kacang) terhadap kualitas produk gula merah. Jurnal Pangan dan Agroindustri. 2(1):97105

Suwanda. 2011. Desain Eksperimen untuk Penelitian Ilmiah. Alfabeta. Bandung

Widiantoko, K, R, Yunianta. 2014. Eksplorasi potensi kedelai hitam untuk produksi minuman fungsional sebagai upaya meningkatkan kesehatan masyarakat. Jurnal Pangan dan Agroindustri. 2(4):5867 
Jurnal Teknologi Pertanian Vol. 19 No. 1 [April 2018] 59-68

Aktivitas Antioksidan, Sifat Fisik dan Sensoris Es Krim [Khairina dkk]

Yanti, T, S. 2010. Perluasan uji kruskal wallis untuk data multivariat. Statistika. 10(1):43-49
Zahro, C, Nisa, F, C. 2015. Pengaruh penambahan sari anggur dan penstabil terhadap karakteristik fisik, kimia, dan organoleptik es krim. Journal Pangan dan Agroindustri. 4(3):1481-1491 